\title{
The risk of ischemic stroke and hemorrhagic stroke in Chinese adults with low-density lipoprotein cholesterol concentrations $<70 \mathrm{mg} / \mathrm{dL}$
}

Zhijun $\mathrm{Wu}^{1+}$, Zhe Huang ${ }^{2+}$, Alice H. Lichtenstein ${ }^{3}$, Yesong Liư ${ }^{4}$, Shuohua Chen ${ }^{5}$, Yao Jin ${ }^{1}$, Muzi Na ${ }^{6}$, Le Bao , Shouling $\mathrm{Wu}^{2^{*}}$ and Xiang Gao ${ }^{6^{*}}$

\begin{abstract}
Background: The risk of stroke in individuals with very low low-density lipoprotein cholesterol (LDL-C) concentrations remains high. We sought to prioritize predictive risk factors for stroke in Chinese participants with LDL-C concentrations $<70 \mathrm{mg} / \mathrm{dL}$ using a survival conditional inference tree, a machine learning method.

Methods: The training dataset included 9327 individuals with LDL-C concentrations $<70 \mathrm{mg} / \mathrm{dL}$ who were free of cardiovascular diseases and did not use lipid-modifying drugs from the Kailuan I study $(N=101,510)$. We examined the validity of this algorithm in a second Chinese cohort of 1753 participants with LDL-C concentrations $<70 \mathrm{mg} /$ dL from the Kailuan II study $(\mathrm{N}=35,856)$.

Results: During a mean 8.5-9.0-year follow-up period, we identified 388 ischemic stroke cases and 145 hemorrhagic stroke cases in the training dataset and 20 ischemic stroke cases and 8 hemorrhagic stroke cases in the validation dataset. Of 15 examined predictors, poorly controlled blood pressure and very low LDL-C concentrations ( $\leq 40 \mathrm{mg} / \mathrm{dL}$ ) were the top hierarchical predictors of both ischemic stroke risk and hemorrhagic stroke risk. The groups, characterized by the presence of 2-3 of aforementioned risk factors, were associated with a higher risk of ischemic stroke (hazard ratio (HR) 7.03; 95\% confidence interval (CI) 5.01-9.85 in the training dataset; HR 4.68, 95\% Cl 1.58-13.9 in the validation dataset) and hemorrhagic stroke ( $\mathrm{HR} 3.94,95 \% \mathrm{Cl} 2.54-6.11$ in the training dataset; HR 4.73, 95\% $0.81-27.6$ in the validation dataset), relative to the lowest risk groups (presence of 0-1 of these factors). There was a linear association between cumulative average LDL-C concentrations and stroke risk. $\mathrm{LDL}-\mathrm{C}$ concentrations $\leq 40 \mathrm{mg} / \mathrm{dL}$ was significantly associated with increased risk of ischemic stroke $(\mathrm{HR} 2.07,95 \% \mathrm{Cl}$ $1.53,2.80)$ and hemorrhagic stroke (HR $2.70,95 \% \mathrm{Cl} 1.70,4.30)$ compared to $\mathrm{LDL}-\mathrm{C}$ concentrations of $55-70 \mathrm{mg} / \mathrm{dL}$, after adjustment for age, hypertension status, and other covariates.
\end{abstract}

\footnotetext{
* Correspondence: drwus|@163.com; xxg14@psu.edu

${ }^{\dagger}$ Zhijun Wu and Zhe Huang contributed equally to this work.

2Department of Cardiology, Kailuan General Hospital, 57 Xinhua East Rd, Tangshan 063000, People's Republic of China

${ }^{6}$ Department of Nutritional Sciences, The Pennsylvania State University, State College, PA, USA

Full list of author information is available at the end of the article
}

(c) The Author(s). 2021 Open Access This article is licensed under a Creative Commons Attribution 4.0 International License, which permits use, sharing, adaptation, distribution and reproduction in any medium or format, as long as you give appropriate credit to the original author(s) and the source, provide a link to the Creative Commons licence, and indicate if changes were made. The images or other third party material in this article are included in the article's Creative Commons licence, unless indicated otherwise in a credit line to the material. If material is not included in the article's Creative Commons licence and your intended use is not permitted by statutory regulation or exceeds the permitted use, you will need to obtain permission directly from the copyright holder. To view a copy of this licence, visit http://creativecommons.org/licenses/by/4.0/ The Creative Commons Public Domain Dedication waiver (http://creativecommons.org/publicdomain/zero/1.0/) applies to the data made available in this article, unless otherwise stated in a credit line to the data. 
Conclusion: Individuals with extremely low LDL-C concentrations without previous lipid-modifying treatment could still be at high stroke risk.

Trial registration: Chinese Clinical Trial Register, ChiCTR-TNRC-11001489. Registered on 24-08-2011.

Keywords: Low-density lipoprotein cholesterol, Stroke, Metabolic diseases, Machine learning, Conditional inference tree

\section{Background}

Low-density lipoprotein cholesterol (LDL-C) has been long regarded as one of the major pathogenic risk factors that increase the risk of cardiovascular diseases (CVD) and cerebrovascular diseases [1]. LDL-C lowering therapy has been demonstrated to be effective in reducing atherosclerotic disease risk substantially [2]. The LDL-C concentration of $70 \mathrm{mg} / \mathrm{dL}$ was considered as an appropriate target goal for optimal lipid management in people who are at high risk of CVD [3-5]. However, emerging observational evidence, suggested that the risk of ischemic stroke $[6,7]$ and hemorrhagic stroke $[8,9]$ remained high among those who had low concentrations of LDL-C. Little is known about the effect of longerterm habitual cumulative exposure to very low LDL-C concentrations (e.g., $<40 \mathrm{mg} / \mathrm{dL}$ ).

It is thus of clinical significance to understand the factors related to the risk of cerebrovascular diseases in the population with low LDL-C concentrations. Whether other metabolic abnormalities (e.g., hypertension, diabetes mellitus, and obesity) contribute to the risk of stroke within the context of a low LDL-C concentration remains unclear. Important to consider, LDL-C concentrations and metabolic and lifestyle risk factors covary and may together have a synergistic or antagonistic effect on stroke-related outcomes.

Recently, machine learning techniques have been widely used for developing risk stratification algorithms due to their intuitive graphical representation [10]. Conditional inference tree is a fundamental machine learning method that recursively partitions participants into the homogenous group with similar outcome probabilities [11], to identify variable importance in the context of high-dimensional interactions [12]. We thus sought to prioritize the strong predictive risk factors of ischemic stroke risk and hemorrhagic stroke risk using a survival conditional inference tree (SCTREE) in a community-based cohort including 9327 participants with LDL-C concentrations $<70 \mathrm{mg} / \mathrm{dL}$ during an 8.5-9.0-year follow-up period. We further validated our findings in another independent cohort including 1753 participants with LDL-C concentrations $<70 \mathrm{mg} / \mathrm{dL}$.

\section{Methods}

\section{Study populations}

We analyzed data from two independent ongoing cohorts-the Kailuan I study was used as the training dataset to develop the risk stratification algorithm, and the Kailuan II study was used as the validation dataset. The study design of these two cohorts has been described in detail previously [13, 14]. Briefly, both cohorts have been conducted in 11 hospitals affiliated with the Kailuan community in Tangshan city, China. The Kailuan I study was initiated in 2006-2007 and consisted of 101,510 Chinese adults (81,110 men and 20,400 women) aged 18 years or older living in the Kailuan community in 2006. The Kailuan II study was initiated in 20082010, including 35,856 adults, who lived in the Kailuan community but did not participate in the Kailuan I study. In both cohorts, participants who completed a questionnaire on demographic details, lifestyle behaviors (e.g., smoking and drinking habits), medication history, and medical comorbidity and underwent clinical and laboratory examinations at baseline and were followed every 2 years with the same strategy to update their health/lifestyle status. Included were 9327 participants in the training dataset and 1753 participants in the validation dataset based on the following criteria: (1) baseline LDL-C concentrations $<70 \mathrm{mg} / \mathrm{dL}$, (2) cumulative average LDL-C concentrations $<70 \mathrm{mg} / \mathrm{dL}$ during the follow-up period (mean follow duration 9.0 and 8.5 years in the Kailuan I and II studies, respectively), (3) without CVD or cancer in or prior to the baseline, and (4) without lipid-modifying drugs at baseline or during the follow-up period (Supplementary Fig. 1).

\section{Assessment of outcomes (incident cases of ischemic stroke and hemorrhagic stroke)}

The primary outcome was the first occurrence of ischemic stroke and hemorrhagic stroke. As previously described $[9,15,16]$, all potential fatal and non-fatal cerebrovascular diseases cases were identified by the relevant International Classification of Diseases (ICD)10th Revision $[17,18]$ from the Municipal Social Insurance Institution (covering all study participants) and the Hospital Discharge Register data and self-report questionnaires during the biennial follow-up surveys. Medical records for all the potential stroke cases were reviewed by 3 cardiologists and neurologists served at a committee of experts. The mortality information was obtained from Hebei Provincial Vital Statistics Offices or directly contacting the participants' family members. Study 
clinicians reviewed death certificates and coded the main cause of death according to the ICD-10. Ischemic stroke and hemorrhagic stroke were defined as a neurological deficit of cerebrovascular cause that lasted more than 24 $\mathrm{h}$ or a significant lesion detected by computed tomography or magnetic resonance imaging [19].

\section{Assessment of potential predictors}

Potential predictors include age, sex, smoking, alcohol intake, physical activity, body mass index, estimated glomerular filtration rate, urine protein, high-sensitivity C-reactive protein, lipid profiles, heart rate, blood pressure, and blood glucose control status (Supplementary Table 1). To take advantage of biennially repeated assessment of predictors, we used cumulative average values of $\mathrm{LDL}-\mathrm{C}$ concentrations and other continuous variables calculated from all available measures since the baseline survey, as previously described $[9,13,20]$. For instance, the average of 2006 and 2008 LDL-C concentrations was used to predict stroke events occurring during 2008-2010; and the average of 2006, 2008, and 2010 measures was used to predict stroke occurring during 2010-2012. This approach allowed us to reduce random within-person variation and capture the long-term effects of studied stroke risk factors.

Information on demographic data, lifestyle factors, and use of medications (e.g., hypoglycemic agents and antihypertensives) was collected using a structured questionnaire [21]. Fasting $(8-12 \mathrm{~h})$ blood samples and random midstream morning urinary samples were collected at baseline and biennial face-to-fact interview and analyzed in the Central Laboratory of Kailuan General Hospital every 2 years. Serum concentrations of 6 traits (LDL-C, high-density lipoprotein cholesterol, triglyceride, glucose, high-sensitivity $\mathrm{C}$-reactive protein, and creatinine) were measured by an auto-analyzer (Hitachi 747; Hitachi, Tokyo, Japan) using commercially available kits, as previously described $[13,20,21]$. The intra-assay and the inter-assay coefficient variation of all the traits were less than $10 \%$. Proteinuria status was assessed using a drychemistry method and standard urinary sediment examination within $2 \mathrm{~h}$ (H12-MA test strips; Changchun Dirui Medical Technology Co., Ltd., Changchun, China) and measured by a urine analyzer (N-600; Changchun Dirui Medical Technology Co., Ltd.). The results were semiquantified as negative $(<15 \mathrm{mg} / \mathrm{dL})$, trace $(15-29 \mathrm{mg} /$ $\mathrm{dL}), 1+(30-300 \mathrm{mg} / \mathrm{dL}), 2+(300-1000 \mathrm{mg} / \mathrm{dL})$, or $3+$ (> $1000 \mathrm{mg} / \mathrm{dL}$ ) [22]. The estimated glomerular filtration rate (eGFR) was calculated according to the Chronic Kidney Disease Epidemiology Collaboration equation considering creatinine, sex, and age [23].

Weight and height were measured by trained field workers (nurses and physicians) during the survey, and body mass index was calculated as weight $(\mathrm{kg}) / \mathrm{height}$ $\left(\mathrm{m}^{2}\right)$.

Systolic blood pressure (SBP) and diastolic blood pressure (DBP) were measured twice from the seated position using a mercury sphygmomanometer, and the mean of the two readings was used for the analyses [14, 24]. Blood pressure control status was classified as follows: (1) wellcontrolled, SBP $<140 \mathrm{mmHg}$ and DBP $<90 \mathrm{mmHg}$ without treatment; (2) well-controlled, SBP $<140 \mathrm{mmHg}$ and DBP $<90 \mathrm{mmHg}$ with certain or uncertain information on drugs; (3) poorly controlled, SBP $\geq 140 \mathrm{mmHg}$ or DBP $\geq 90 \mathrm{mmHg}$ without treatment; and (4) poorly controlled, $\mathrm{SBP} \geq 140 \mathrm{mmHg}$ or DBP $\geq 90 \mathrm{mmHg}$ with certain or uncertain information on drugs. Heart rate was detected by electrocardiogram at baseline and during follow-up surveys, as described previously [13, 24].

Given a long-term effect of high hyperglycemia on cerebrovascular disease occurrence, we classified all participants into 4 categories according to their glycemic control levels: (1) well-controlled, fasting blood glucose (FBG) $<126 \mathrm{mg} / \mathrm{dL}$ without administration of glucoselowering drugs; (2) well-controlled, FBG $<126 \mathrm{mg} / \mathrm{dL}$ with certain or uncertain information on drugs; (3) poorly controlled, $\mathrm{FBG} \geq 126 \mathrm{mg} / \mathrm{dL}$ without treatment; and (4) poorly controlled, FBG $\geq 126 \mathrm{mg} / \mathrm{dL}$ with certain or uncertain information on drugs (Supplementary Table $1)$.

\section{Statistical analysis}

The person-time for each participant was calculated from the date of the baseline survey to the date of any stroke event diagnosis, lost to follow-up due to migrations or other reason $(8.53 \%)$, mortality, or the end of follow-up, 31 December 2016, whichever came first.

The SCTREE model was used to develop a risk stratification algorithm for stroke risk in the Kailuan I study with 15 candidate attributes (Supplementary Table 1). SCTREE recursively partitions the dataset into smaller subsets for selecting the top predictor and corresponding cutoff value with the largest weighted Kaplan-Meier estimate. The incidence of stroke cases and survival time within each terminal node were calculated to generate an associated risk stratification tree.

The hazard ratios (HRs) and 95\% confidence intervals (CIs) were calculated to compare the stroke risk across the risk groups generated by SCTREE. The performance of the SCTREE-developed risk stratification algorithm was further evaluated and compared using the validation dataset (the Kailuan II study).

We also conducted multivariate Cox regression and propensity score-matched Cox regression including the same predictors that were identified by the SCTREE analysis. The predictive ability and accuracy of the SCTREE and multivariate Cox models were compared 
using area under the receiver operating characteristic curves (AUC) [25] and Brier score [26]. A higher AUC with a lower Brier score was considered as a better prediction performance.

A Cox proportional hazards model was used to assess the association between the cumulative average values of LDL-C according to predefined groups with clinically meaningful cutoffs $(\leq 40 \mathrm{mg} / \mathrm{dL}, 40-55 \mathrm{mg} / \mathrm{dL}$, and $55-$ $70 \mathrm{mg} / \mathrm{dL}$ ) [27] and quartiles, and stroke risk. We also conducted other sensitivity analyses by excluding participants with eGFR $<60 \mathrm{ml} / \mathrm{min} / 1.73 \mathrm{~m}^{2}$ or a 10-year Framingham risk score $>30 \%$ [28]. Considering malnutrition, as suggested by low BMI, which was associated with low concentrations of LDL-C and increased risk of stroke, we performed a sensitivity analysis by excluding participants with BMI $<18.5 \mathrm{~kg} / \mathrm{m}^{2}$ [29]. To remove the confounding effect of treatment of hypertension or diabetes mellitus, we further performed sensitivity analyses by excluding those who used blood pressure-lowering drugs or glucose-lowering drugs.

We used the random survival forests algorithm on all 15 variables to validate the risk precision of the SCTREE model. The variables at a higher rank had a smaller minimal depth of a maximal subtree (a shorter distance from the root node to the parent node of the closest maximal subtree). We extracted the variable importance (VIMP) of each individual predictor to reflect the predictive abilities of the variables identified by the random survival forests algorithm [30]. Since VIMP is the increase of prediction errors after permuting the variable under consideration, a positive VIMP value indicates the variable improves the prediction accuracy, and a negative VIMP value indicates the variable leads to overfitting [31].

All statistical analyses were conducted using the $\mathrm{R}$ version 3.6.3 software ( $\mathrm{R}$ Foundation for Statistical Computing, Vienna, Austria) and STATA12.0 (Stata Corporation, College Station, TX, USA). All statistical tests were 2 -sided with a $\mathrm{P}$ value $<0.05$ regarded as significant.

\section{Results}

The cumulative average LDL-C concentrations of the training and validation datasets were similar. In contrast, participants in the validation cohort were younger and had a higher proportion of women, smoker, and drinker; low BMI; high level of heart rate and eGFR; high concentrations of triglyceride and LDL-C; and low concentrations of high-density lipoprotein cholesterol and engaged in a low level of physical activity and wellcontrolled blood pressure and blood glucose (Table 1). Identified were 388 ischemic stroke cases and 145 hemorrhagic stroke cases in the Kailuan I study with a mean of 9.0 years of follow-up and 20 ischemic stroke cases and 8 hemorrhagic stroke in the Kailuan II study with a mean of 8.5 years of follow-up.

Of the 15 variables that were examined, the first risk factor identified was blood pressure control status, followed by age and LDL-C concentrations for ischemic stroke. Participants (i) with poorly controlled blood pressure and LDL-C concentrations $\leq 33.2 \mathrm{mg} / \mathrm{dL}$ and (ii) with well-controlled blood pressure, aged $>64.9$ years, and LDL-C concentrations $\leq 32.0 \mathrm{mg} / \mathrm{dL}$ had the highest ischemic stroke risk among the 9 sub-groups identified by the SCTREE model (Fig. 1). The HRs for these highrisk sub-groups, compared with the sub-group with the lowest stroke risk (well-controlled blood pressure and age $\leq 54.1$ years $)$, were more than $20(\mathrm{P}<0.001$ for all $)$ (Table 2).

Poorly controlled blood pressure and low LDL-C concentrations were identified as the main top discriminators for hemorrhagic stroke (Fig. 2 and Supplementary Table 2). Participants with poorly controlled blood pressure and LDL-C concentrations $\leq 32.8 \mathrm{mg} / \mathrm{dL}$ had the highest hemorrhagic stroke risk compared to those with well-controlled blood pressure, LDL-C concentrations > $40.2 \mathrm{mg} / \mathrm{dL}$, and aged $\leq 64.8$ years (HR 41.7, 95\%CI $17.2-$ 101.6). Similar results were observed by excluding participants with eGFR $<60 \mathrm{ml} / \mathrm{min} / 1.73 \mathrm{~m}^{2}, 10$-year Framingham risk score $>30 \%$, BMI $<18.5 \mathrm{~kg} / \mathrm{m}^{2}$, or who used blood pressure-lowering drugs or glucose-lowering drugs (Table 2).

The Kailuan I study participants were stratified into high ( $>5 \%$ developed ischemic stroke; $\mathrm{n}=4548)$, intermediate $(3-5 \%$ developed ischemic stroke; $\mathrm{n}=2840)$, and low $(<3 \%$ developed ischemic stroke; $\mathrm{n}=1939)$ risk groups. The ability of the derived risk tree to stratify participants into these groups was tested in the validation dataset (the Kailuan II study). A similar doseresponse trend across the 3 risk groups for ischemic stroke was observed-the HRs for the high- versus lowrisk groups were 7.03 (95\%CI 5.01-9.85) in the training dataset and 4.68 (5\% CI 1.58-13.9) in the validation dataset. The HRs for the high-risk group ( $>2 \%$ developed hemorrhagic stroke, $\mathrm{n}=5468$ ) versus the low-risk group $(<2 \%$ developed hemorrhagic stroke, $\mathrm{n}=3859)$ were 3.94 (95\% CI 2.54-6.11) in the training dataset and 4.73 (5\%CI 0.81-27.6) in the validation dataset (Fig. 3). The SCTREE model had a similar AUC and Brier score relative to the multivariate Cox model (Supplementary Table 3). The random survival forest analysis showed that blood pressure control and LDL-C concentrations were among the top predictors for both ischemic stroke and hemorrhagic stroke, and age was a strong predictor for ischemic stroke, which was consistent with the results of the SCTREE model (Supplementary Fig. 2). When we turned the outcomes into a classification one (stroke versus non-stroke event), the results did not 
Table 1 Baseline characteristics of Kailuan I study (training dataset) and Kailuan II study (validation dataset) participants with lowdensity lipoprotein cholesterol concentrations $<70$ mg/dL

\begin{tabular}{|c|c|c|}
\hline & Training dataset (Kailuan I study) & Validation dataset (Kailuan II study) \\
\hline Number & 9327 & 1753 \\
\hline Age, years & $57.3 \pm 13.7^{\mathrm{a}}$ & $43.6 \pm 15.1$ \\
\hline Men, \% & 78.8 & 70.3 \\
\hline $\mathrm{BMI}, \mathrm{kg} / \mathrm{m}^{2}$ & $24.2 \pm 3.39$ & $23.8 \pm 3.51$ \\
\hline $\mathrm{TG}, \mathrm{mg} / \mathrm{dL}$ & $144.4 \pm 144.1$ & $170.3 \pm 186.5$ \\
\hline $\mathrm{LDL}-\mathrm{C}, \mathrm{mg} / \mathrm{dL}$ & $55.6 \pm 12.6$ & $57.4 \pm 10.4$ \\
\hline $\mathrm{HDL}-\mathrm{C}, \mathrm{mg} / \mathrm{dL}$ & $58.5 \pm 17.5$ & $53.4 \pm 15.7$ \\
\hline $\mathrm{HR}$, bpm & $73.6 \pm 9.48$ & $74.1 \pm 8.80$ \\
\hline $\mathrm{eGFR}, \mathrm{ml} / \mathrm{min} / 1.73 \mathrm{~m}^{2}$ & $88.4 \pm 19.0$ & $97.8 \pm 21.9$ \\
\hline hs-CRP, mg/L ${ }^{b}$ & $0.48 \pm 1.29$ & $0.47 \pm 1.04$ \\
\hline \multicolumn{3}{|l|}{ Urine protein } \\
\hline Negative & 89.8 & 88.8 \\
\hline Trace & 6.28 & 3.04 \\
\hline+ & 2.38 & 6.55 \\
\hline++ & 1.05 & 1.17 \\
\hline+++ & 0.54 & 0.47 \\
\hline \multicolumn{3}{|l|}{ Physical activity, \% } \\
\hline Inactive & 5.41 & 24.1 \\
\hline Moderately active & 81.7 & 60.0 \\
\hline Vigorously active & 12.9 & 15.9 \\
\hline Current smoker, \% & 28.8 & 39.5 \\
\hline Current drinker, \% & 31.1 & 39.4 \\
\hline \multicolumn{3}{|c|}{ Blood pressure control, \% } \\
\hline Well-controlled & 63.9 & 70.4 \\
\hline Poorly controlled & 36.1 & 29.6 \\
\hline \multicolumn{3}{|l|}{ Blood glucose control, \% } \\
\hline Well-controlled & 91.8 & 92.7 \\
\hline Poorly controlled & 8.26 & 7.26 \\
\hline
\end{tabular}

Abbreviations: $B M I$, body mass index; $T G$, triglyceride; $L D L-C$, low-density lipoprotein cholesterol; $H D L-C$, high-density lipoprotein cholesterol; $H R$, heart rate; eGFR, estimated glomerular filtration rate; $h s-C R P$, high-sensitivity $C$-reactive protein

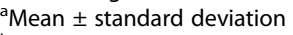

${ }^{b}$ hs-CRP was log-transformed

materially change. Poorly controlled blood pressure and low LDL-C concentrations remained the top predictors of ischemic stroke and hemorrhagic stroke (Supplementary Fig. 3 \& 4).

There was a linear association between cumulative average LDL-C concentrations and stroke risk. Very low LDL-C concentrations $(<40 \mathrm{mg} / \mathrm{dL})$ were significantly associated with increased risk of ischemic stroke (HR 2.07, 95\%CI 1.53, 2.80) and hemorrhagic stroke (HR 2.70, 95\%CI 1.70, 4.30) compared to LDL-C concentrations of $55-70 \mathrm{mg} /$ $\mathrm{dL}$. These results were further confirmed using a quartile-based analysis ( $P_{\text {trend }}<0.01$ for both) (Table 3).

\section{Discussion}

Using data from 2 community-based cohorts and a machine learning approach, we found that in participants with LDL-C concentrations $<70 \mathrm{mg} / \mathrm{dL}$, and not receiving lipid-lowering therapy, the major attributes of stroke risk were very low LDL-C concentrations and poorly controlled blood pressure. The highest risk group, characterized by the presence of $2-3$ of these risk factors, was at high risk of developing stroke during the 8.5- to 9-year follow-up period relative to the lowest risk group when predicted using either the training or the validation datasets. There was remarkable consistency between the two datasets. We further confirmed the association between low LDL-C concentrations and 


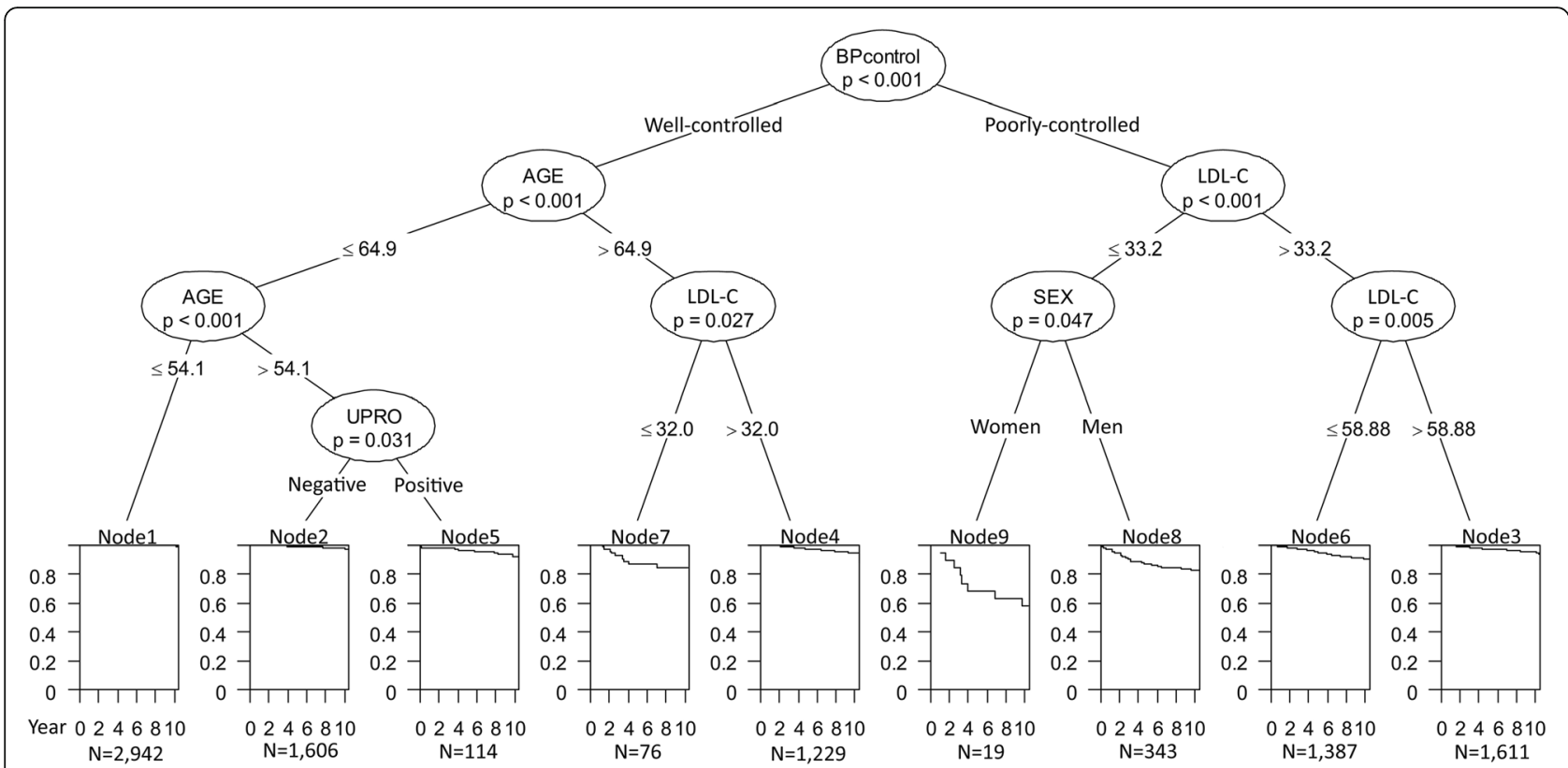

Fig. 1 Conditional inference tree for ischemic stroke in individuals with low-density lipoprotein cholesterol concentrations < 70 mg/dL in the Kailuan I study. The terminal nodes show the Kaplan-Meier curves. BP, blood pressure; LDL-C, low-density lipoprotein cholesterol; UPRO, urine protein

stroke risk using the traditional Cox proportional hazards model. For the primary prevention of stroke, these findings highlight the need for a better understanding of the influence of potential confounders in individuals with very low LDL-C concentrations in the absence of therapy.

The predictive models indicated that individuals with very low LDL-C concentrations without the influence of lipid-lowing drugs were still at elevated risk for stroke. One possible interpretation of these findings is that a very low LDL-C concentration is a marker of a chronic metabolic disorder and associated adverse sequelae of the disorder such as high inflammatory burden. Systemic chronic inflammation may lead to very low blood LDL$\mathrm{C}$ concentrations by exacerbating cholesterol accumulation into macrophages [32]. Therefore, non-treatment and on-treatment low LDL-C concentrations may have different associations with cerebrovascular disease. Whether the observed results could apply to intervention trials remains to be elucidated.

Our study suggested the appropriate concentration of LDL-C below which stroke events identified was $33 \mathrm{mg} /$ $\mathrm{dL}$. Interestingly, this level is similar to the neonatal LDL-C concentrations at birth $(21-39 \mathrm{mg} / \mathrm{dL})$ [33]. Cholesterol is a constituent of cell membranes, hence, essential to maintain cellular structural integrity and serves as a precursor for bioactive compounds, ranging from steroid hormones to vitamin D. Plasma LDL-C concentrations of $21-39 \mathrm{mg} / \mathrm{dL}$ have been suggested to be the lower limit that will sustain normal cellular function [34-36]. In the Reasons for Geographical and Racial Differences in Stroke (REGARDS) study, participants with high LDL-C $(\geq 70 \mathrm{mg} / \mathrm{dL})$ and low hs-CRP (< $2 \mathrm{mg} / \mathrm{L}$ ) had a lower risk of stroke [37]. A recent randomized trial reported that high-dose atorvastatin significantly reduced the overall incidence of stroke and CVD but increased the risk of hemorrhagic stroke [38]. Three recent large-scale observational studies reported that LDL-C concentrations $<70 \mathrm{mg} / \mathrm{dL}$ were positively associated with hemorrhagic stroke risk $[8,9]$. The causal relevance of these observed associations between low LDL-C concentrations and hemorrhagic stroke was confirmed in a meta-analysis of LDL-C-lowering intervention and a Mendelian randomization analysis [39]. Interestingly, another Mendelian randomization analysis reported that decrement of the LDL-C concentrations may lead to decreased CVD risk but increased DM risk [40].

Of note, some guidelines [2, 41], although not consistently [27], comment on the potential adverse effect of very low LDL-C concentrations, in the range of 25 to $70 \mathrm{mg} /$ $\mathrm{dL}$, achieved with lipid-lowering therapy. The recent 2019 European Society of Cardiology/European Atherosclerosis Society lipid guidelines recommended a lower LDL-C goal (e.g., $<55 \mathrm{mg} / \mathrm{dL}$ ) than the previous guidelines for individuals at very-high CVD risk [27]. The authors of the guidelines indicated there are no known adverse effects of LDLC concentrations $<40 \mathrm{mg} / \mathrm{dL}$ [27].

Our result suggested poorly controlled blood pressure contributed to the risk of stroke in individuals with very low LDL-C concentrations. Poorly controlled blood 
Table 2 Adjusted hazards ratios and 95\% confidence intervals for the risk of ischemic stroke and hemorrhagic stroke across terminal nodes in the Kailuan I participants with low-density lipoprotein cholesterol concentrations $<70 \mathrm{mg} / \mathrm{dL}$

\begin{tabular}{|c|c|c|c|c|c|c|c|c|c|}
\hline & \multicolumn{9}{|c|}{ Ischemic stroke, HR (95\%Cl) } \\
\hline & Node1 & Node2 & Node3 & Node4 & Node5 & Node6 & Node7 & Node8 & Node9 \\
\hline Case/person-years & $15 / 28,515$ & $37 / 15,483$ & $78 / 14,743$ & $60 / 10,818$ & $8 / 1026$ & $119 / 12,021$ & $10 / 547$ & $53 / 2553$ & $8 / 143$ \\
\hline $\mathrm{LDL}-\mathrm{C} \pm \mathrm{SD}, \mathrm{mg} / \mathrm{dL}$ & $56.8 \pm 10.9$ & $57.3 \pm 10.8$ & $64.6 \pm 3.03$ & $57.7 \pm 8.76$ & $55.6 \pm 11.9$ & $50.1 \pm 6.48$ & $19.2 \pm 8.90$ & $20.3 \pm 8.53$ & $20.6 \pm 9.63$ \\
\hline Multivariate model $^{\mathrm{a}}$ & $\begin{array}{l}1.00 \\
\text { (reference) }\end{array}$ & $\begin{array}{l}3.73(2.01 \\
6.92)\end{array}$ & $\begin{array}{l}7.07(3.98, \\
12.6)\end{array}$ & $\begin{array}{l}7.38(4.05 \\
13.4)\end{array}$ & $\begin{array}{l}8.44(3.04 \\
23.4)\end{array}$ & $\begin{array}{l}13.0(7.41 \\
22.7)\end{array}$ & $\begin{array}{l}20.8(7.86, \\
54.8)\end{array}$ & $\begin{array}{l}23.1(12.4 \\
43.1)\end{array}$ & $\begin{array}{l}76.3(30.2 \\
192.7)\end{array}$ \\
\hline $\begin{array}{l}\text { Excluding eGFR }<60 \mathrm{ml} / \mathrm{min} / \\
1.73 \mathrm{~m}^{2}\end{array}$ & $\begin{array}{l}1.00 \\
\text { (reference) }\end{array}$ & $\begin{array}{l}3.60(1.94 \\
6.70)\end{array}$ & $\begin{array}{l}6.06(3.37 \\
10.9)\end{array}$ & $\begin{array}{l}7.10(3.85 \\
13.1)\end{array}$ & $\begin{array}{l}8.86(3.19 \\
24.6)\end{array}$ & $\begin{array}{l}12.8(7.30 \\
22.4)\end{array}$ & $\begin{array}{l}18.9(6.69, \\
53.4)\end{array}$ & $\begin{array}{l}24.6(13.1 \\
46.2)\end{array}$ & $\begin{array}{l}62.2(23.3 \\
166.3)\end{array}$ \\
\hline $\begin{array}{l}\text { Excluding Framingham risk } \\
\text { score }>30 \%\end{array}$ & $\begin{array}{l}1.00 \\
\text { (reference) }\end{array}$ & $\begin{array}{l}3.82(2.02, \\
7.23)\end{array}$ & $\begin{array}{l}6.41(3.38 \\
12.1)\end{array}$ & $\begin{array}{l}6.71(3.29 \\
13.7)\end{array}$ & $\begin{array}{l}10.4(3.74 \\
29.2)\end{array}$ & $\begin{array}{l}12.3(6.74 \\
22.4)\end{array}$ & $\begin{array}{l}24.2(6.74 \\
86.6)\end{array}$ & $\begin{array}{l}23.3(11.2 \\
48.1)\end{array}$ & $\begin{array}{l}76.8(24.7 \\
238.3)\end{array}$ \\
\hline Excluding $\mathrm{BMI}<18.5 \mathrm{~kg} / \mathrm{m}^{2}$ & $\begin{array}{l}1.00 \\
\text { (reference) }\end{array}$ & $\begin{array}{l}3.75(2.02 \\
6.94)\end{array}$ & $\begin{array}{l}7.01(3.94 \\
12.5)\end{array}$ & $\begin{array}{l}7.51(4.12 \\
13.7)\end{array}$ & $\begin{array}{l}8.37(3.02 \\
23.2)\end{array}$ & $\begin{array}{l}13.0(7.45 \\
22.8)\end{array}$ & $\begin{array}{l}21.9(8.29 \\
57.9)\end{array}$ & $\begin{array}{l}23.1(12.4 \\
43.1)\end{array}$ & $\begin{array}{l}74.5(29.5 \\
188.2)\end{array}$ \\
\hline $\begin{array}{l}\text { Excluding blood pressure- } \\
\text { lowering drugs }\end{array}$ & $\begin{array}{l}1.00 \\
\text { (reference) }\end{array}$ & $\begin{array}{l}3.48(1.85 \\
6.56)\end{array}$ & $\begin{array}{l}6.49(3.50 \\
12.0)\end{array}$ & $\begin{array}{l}7.24(3.88, \\
13.5)\end{array}$ & $\begin{array}{l}9.26(3.32 \\
25.8)\end{array}$ & $\begin{array}{l}11.0(6.10 \\
19.8)\end{array}$ & $\begin{array}{l}22.0(8.24 \\
59.0)\end{array}$ & $\begin{array}{l}22.3(11.5 \\
43.2)\end{array}$ & $\begin{array}{l}52.1(16.8 \\
161.5)\end{array}$ \\
\hline \multirow[t]{3}{*}{$\begin{array}{l}\text { Excluding glucose-lowering } \\
\text { drugs }\end{array}$} & $\begin{array}{l}1.00 \\
\text { (reference) }\end{array}$ & $\begin{array}{l}3.69(1.98 \\
6.87)\end{array}$ & $\begin{array}{l}6.92(3.87 \\
12.4)\end{array}$ & $\begin{array}{l}7.81(4.27 \\
14.3)\end{array}$ & $\begin{array}{l}9.35(3.36, \\
26.0)\end{array}$ & $\begin{array}{l}13.1(7.49 \\
23.0)\end{array}$ & $\begin{array}{l}18.0(6.39 \\
50.7)\end{array}$ & $\begin{array}{l}21.8(11.6 \\
40.9)\end{array}$ & $\begin{array}{l}63.1(23.7 \\
168.0)\end{array}$ \\
\hline & \multicolumn{9}{|c|}{ Hemorrhagic stroke, HR $(95 \% \mathrm{Cl})$} \\
\hline & Node1 & \multicolumn{2}{|l|}{ Node2 } & Node3 & \multicolumn{2}{|l|}{ Node4 } & Node5 & \multicolumn{2}{|l|}{ Node6 } \\
\hline Case/person-years & $13 / 41,704$ & \multicolumn{2}{|l|}{$13 / 4435$} & 19/10,553 & \multicolumn{2}{|l|}{$75 / 27,377$} & $12 / 2102$ & \multicolumn{2}{|l|}{$13 / 739$} \\
\hline $\mathrm{LDL}-\mathrm{C} \pm \mathrm{SD}, \mathrm{mg} / \mathrm{dL}$ & $59.3 \pm 7.25$ & \multicolumn{2}{|l|}{$28.9 \pm 9.75$} & $58.8 \pm 7.51$ & \multicolumn{2}{|l|}{$57.8 \pm 8.82$} & $19.9 \pm 8.60$ & \multicolumn{2}{|l|}{$20.2 \pm 8.03$} \\
\hline Multivariate model $^{a}$ & $\begin{array}{l}1.00 \\
\text { (reference) }\end{array}$ & \multicolumn{2}{|c|}{$4.40(2.07,9.33)$} & $\begin{array}{l}6.59(3.55 \\
12.2)\end{array}$ & \multicolumn{2}{|c|}{$5.41(2.22,13.2)$} & $\begin{array}{l}9.74(3.84 \\
24.7)\end{array}$ & \multicolumn{2}{|c|}{$41.7(17.2,101.6)$} \\
\hline $\begin{array}{l}\text { Excluding eGFR }<60 \mathrm{ml} / \mathrm{min} / \\
1.73 \mathrm{~m}^{2}\end{array}$ & $\begin{array}{l}1.00 \\
\text { (reference) }\end{array}$ & \multicolumn{2}{|c|}{$4.58(2.13,9.85)$} & $\begin{array}{l}6.55(3.52 \\
12.2)\end{array}$ & \multicolumn{2}{|c|}{$4.68(1.84,11.9)$} & $\begin{array}{l}9.98(3.78 \\
26.4)\end{array}$ & \multicolumn{2}{|c|}{$37.5(15.3,91.6)$} \\
\hline $\begin{array}{l}\text { Excluding Framingham risk } \\
\text { score }>30 \%\end{array}$ & $\begin{array}{l}1.00 \\
\text { (reference) }\end{array}$ & \multicolumn{2}{|c|}{$5.09(2.02,12.8)$} & $\begin{array}{l}5.01(2.51 \\
9.99)\end{array}$ & \multicolumn{2}{|c|}{$4.11(1.52,11.1)$} & $\begin{array}{l}10.7(3.25 \\
35.2)\end{array}$ & \multicolumn{2}{|c|}{$21.3(6.86,65.9)$} \\
\hline Excluding $\mathrm{BMI}<18.5 \mathrm{~kg} / \mathrm{m}^{2}$ & $\begin{array}{l}1.00 \\
\text { (reference) }\end{array}$ & \multicolumn{2}{|c|}{$4.52(2.13,9.59)$} & $\begin{array}{l}6.46(3.48, \\
12.0)\end{array}$ & \multicolumn{2}{|c|}{$4.85(1.91,12.3)$} & $\begin{array}{l}9.71(3.82, \\
24.7)\end{array}$ & \multicolumn{2}{|c|}{$42.6(17.4,104.2)$} \\
\hline $\begin{array}{l}\text { Excluding blood pressure- } \\
\text { lowering drugs }\end{array}$ & $\begin{array}{l}1.00 \\
\text { (reference) }\end{array}$ & \multicolumn{2}{|c|}{$3.55(1.57,8.03)$} & $\begin{array}{l}5.39(2.78 \\
10.4)\end{array}$ & \multicolumn{2}{|c|}{$5.03(2.05,12.4)$} & $\begin{array}{l}7.73(2.60 \\
23.1)\end{array}$ & \multicolumn{2}{|c|}{$34.0(12.8,89.9)$} \\
\hline $\begin{array}{l}\text { Excluding glucose-lowering } \\
\text { drugs }\end{array}$ & $\begin{array}{l}1.00 \\
\text { (reference) }\end{array}$ & \multicolumn{2}{|c|}{$4.56(2.14,9.69)$} & $\begin{array}{l}6.42(3.44 \\
12.0)\end{array}$ & \multicolumn{2}{|c|}{$5.52(2.26,13.5)$} & $\begin{array}{l}10.2(4.00 \\
25.8)\end{array}$ & \multicolumn{2}{|c|}{$38.1(15.2,95.4)$} \\
\hline
\end{tabular}

Abbreviations: $H R$, hazard ratio; $C l$, confidence interval; $L D L-C$, low-density lipoprotein cholesterol; $S D$, standard deviation; eGFR, estimated glomerular filtration rate; $B M I$, body mass index

${ }^{a}$ All models were adjusted for sex (men or women), age (year), physical activity (inactive, moderately active, or vigorously active), smoking and drinking status (never, former, occasional or daily), blood pressure status during follow-up (well-controlled or poorly controlled), blood glucose status during follow-up (wellcontrolled or poorly controlled), body mass index $\left(\mathrm{kg} / \mathrm{m}^{2}\right)$, urine protein (negative, trace,,+++ , or +++$)$, heart rate $(\mathrm{bpm})$, triglyceride $(\mathrm{mg} / \mathrm{dL})$, high-density lipoprotein cholesterol (mg/dL), low-density lipoprotein cholesterol ( $\mathrm{mg} / \mathrm{dL}$ ), estimated glomerular filtration rate $\left(\mathrm{ml} / \mathrm{min} / 1.73 \mathrm{~m}{ }^{2}\right)$, and high-sensitivity C-reactive protein $(\mathrm{mg} / \mathrm{L})$

pressure or glucose conferred 1.5-2-fold increased risk of stroke [42]. Individuals of Asian descent have a higher prevalence of metabolic syndrome than of Caucasians [41]. Solely increment in lowering LDL-C is not as effective in reducing atherosclerotic risk more in Asians compared to Caucasians. The Evaluation of Cardiovascular Outcomes After an Acute Coronary Syndrome During Treatment with Alirocumab study demonstrated that LDL-C lowering with alirocumab significantly reduced the primary CVD outcomes in North Americans (HR 0.78, 95\%CI 0.65-0.94), but not in Asians (HR 1.03, 95\%CI 0.76-1.38) [43].

Our study has several strengths, including its large sample size of participants with LDL-C concentrations
$<70 \mathrm{mg} / \mathrm{dL}$. The SCTREE analysis, beyond the traditional statistical analyses, provides a robust framework for testing attributes that are predictive of stroke risk taking the complex high-order interactions into account. We excluded people using lipid-modifying drugs to reduce the sources of potential confounding related to these medications. The ability to use cumulative average values for all continuous variables in the SCTREE model reduced the possibility of "regression dilution."

Our study has several limitations. Our study is based on two Chinese cohorts, which limits the generalizability of our findings to other ethnic groups. Further, the mean age of the validation cohort (43.6 years) was much lower than that of the training cohort (57.3 years), which 


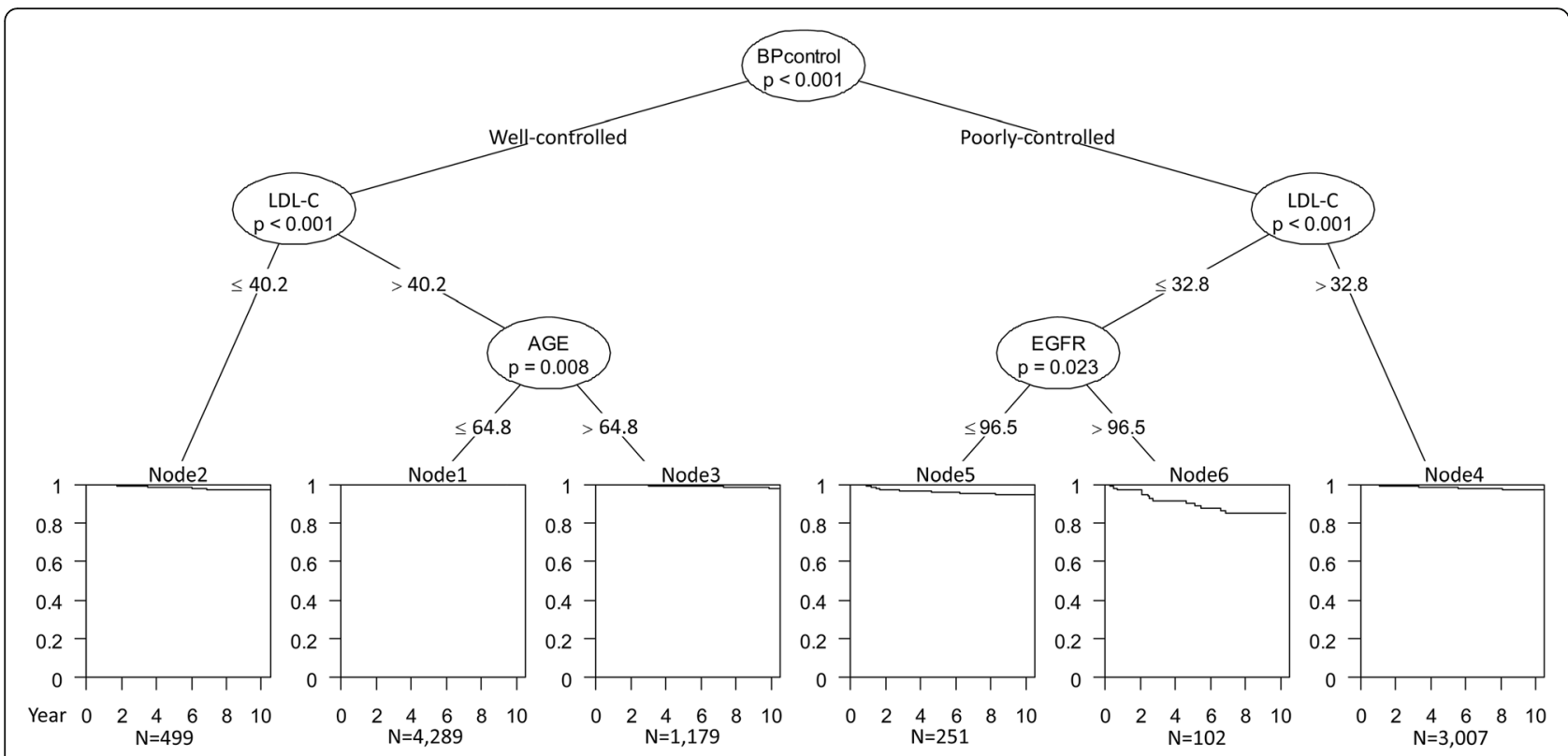

Fig. 2 Conditional inference tree for hemorrhagic stroke in individuals with low-density lipoprotein cholesterol concentrations $<70 \mathrm{mg} / \mathrm{dL}$ in the Kailuan I study. The terminal nodes show the Kaplan-Meier curves. BP, blood pressure; LDL-C, low-density lipoprotein cholesterol; eGFR, estimated glomerular filtration rate

\section{Ischemic stroke}

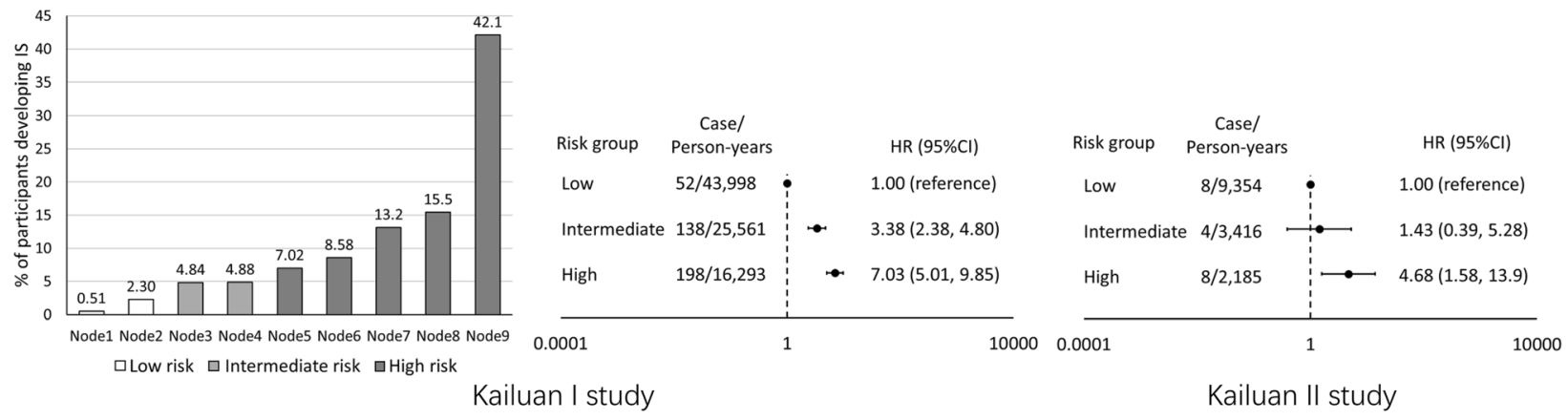

\section{Hemorrhagic stroke}

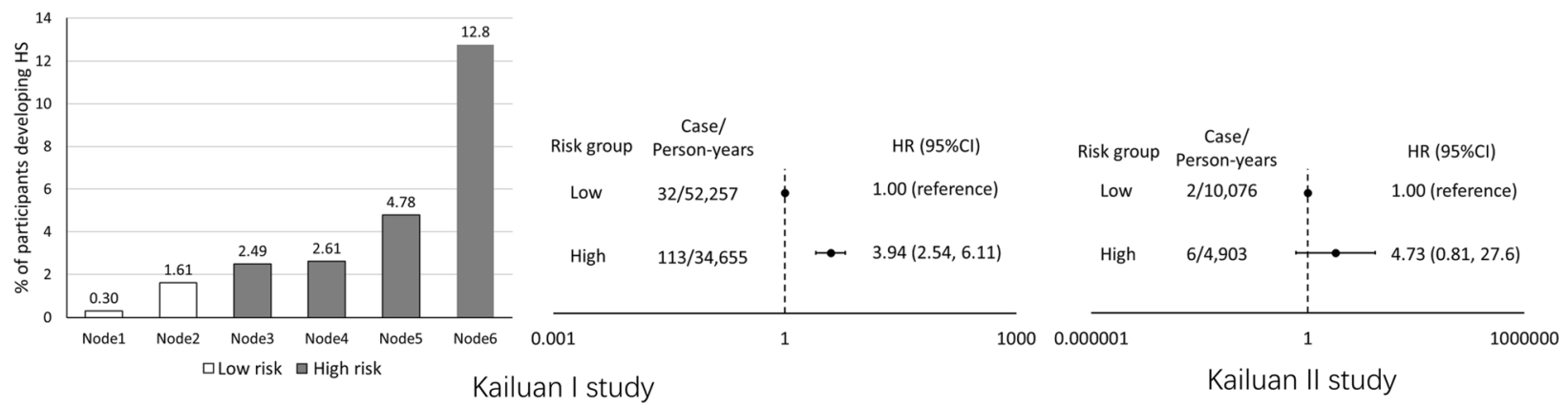

Fig. 3 Percentages of participants who developed ischemic stroke and hemorrhagic stroke during follow-up and adjusted hazard ratios (HRs) and 95\% confidence intervals (Cls) across the risk groups in individuals with low-density lipoprotein cholesterol concentrations $<70 \mathrm{mg} / \mathrm{dL}$ in the Kailuan I study and the Kailuan II study. IS, ischemic stroke; HS, hemorrhagic stroke 
Table 3 Adjusted hazards ratios and 95\% confidence intervals for ischemic stroke risk and hemorrhagic risk according to lowdensity lipoprotein cholesterol clinical cutoffs and quartiles in Kailuan I study participants with low-density lipoprotein cholesterol concentrations $<70 \mathrm{mg} / \mathrm{dL}$

\begin{tabular}{|c|c|c|c|c|c|c|c|c|c|c|}
\hline \multirow{3}{*}{$\overline{L D L-C, ~ m m o l / L}$} & \multicolumn{5}{|c|}{ Ischemic stroke } & \multicolumn{5}{|c|}{ Hemorrhagic stroke } \\
\hline & \multicolumn{5}{|c|}{ HR $(95 \% \mathrm{Cl})$} & \multicolumn{5}{|c|}{ HR (95\%Cl) } \\
\hline & $\leq 40$ & \multicolumn{2}{|l|}{$40-55$} & \multicolumn{2}{|l|}{$55-70$} & $\leq 40$ & \multicolumn{2}{|l|}{$40-55$} & \multicolumn{2}{|l|}{$55-70$} \\
\hline Number & 982 & \multicolumn{2}{|l|}{2374} & \multicolumn{2}{|l|}{5971} & 982 & \multicolumn{2}{|l|}{2374} & \multicolumn{2}{|l|}{5971} \\
\hline Case/person-years & $90 / 8034$ & \multicolumn{2}{|l|}{$110 / 21,570$} & \multicolumn{2}{|l|}{$188 / 56,249$} & $42 / 8341$ & \multicolumn{2}{|l|}{$34 / 21,846$} & \multicolumn{2}{|l|}{$69 / 56,725$} \\
\hline Mean $\mathrm{LDL}-\mathrm{C} \pm \mathrm{SD}, \mathrm{mg} / \mathrm{dL}$ & $\begin{array}{l}26.7 \pm \\
10.3\end{array}$ & \multicolumn{2}{|l|}{$49.1 \pm 4.05$} & \multicolumn{2}{|l|}{$63.0 \pm 4.10$} & $\begin{array}{l}26.7 \pm \\
10.3\end{array}$ & \multicolumn{2}{|l|}{$49.1 \pm 4.05$} & \multicolumn{2}{|l|}{$63.0 \pm 4.10$} \\
\hline Multivariate model $^{a}$ & $\begin{array}{l}2.07(1.53 \\
2.80)\end{array}$ & \multicolumn{2}{|c|}{$1.43(1.11,1.84)$} & \multicolumn{2}{|c|}{1.00 (reference) } & $\begin{array}{l}2.70(1.70 \\
4.30)\end{array}$ & \multicolumn{2}{|c|}{$1.16(0.74,1.80)$} & \multicolumn{2}{|c|}{1.00 (reference) } \\
\hline $\begin{array}{l}\text { Excluding eGFR }<60 \mathrm{ml} / \mathrm{min} / \\
1.73 \mathrm{~m}^{2}\end{array}$ & $\begin{array}{l}2.21(1.60, \\
3.07)\end{array}$ & \multicolumn{2}{|c|}{$1.53(1.17,2.00)$} & \multicolumn{2}{|c|}{1.00 (reference) } & $\begin{array}{l}2.65(1.63 \\
4.30)\end{array}$ & \multicolumn{2}{|c|}{$1.13(0.72,1.77)$} & \multicolumn{2}{|c|}{1.00 (reference) } \\
\hline $\begin{array}{l}\text { Excluding Framingham risk } \\
\text { score }>30 \%\end{array}$ & $\begin{array}{l}2.37(1.57 \\
3.58)\end{array}$ & \multicolumn{2}{|c|}{$1.48(1.04,2.10)$} & \multicolumn{2}{|c|}{1.00 (reference) } & $\begin{array}{l}2.60(1.39 \\
4.86)\end{array}$ & \multicolumn{2}{|c|}{$1.00(0.53,1.88)$} & \multicolumn{2}{|c|}{1.00 (reference) } \\
\hline Excluding $\mathrm{BMI}<18.5 \mathrm{~kg} / \mathrm{m}^{2}$ & $\begin{array}{l}2.09(1.54 \\
2.84)\end{array}$ & $1.45(1.13$ & 1.87) & 1.00 (referer & ce) & $\begin{array}{l}2.69(1.68 \\
4.31)\end{array}$ & $1.19(0.76$ & 1.85) & 1.00 (refere & cce) \\
\hline $\begin{array}{l}\text { Excluding blood pressure- } \\
\text { lowering drugs }\end{array}$ & $\begin{array}{l}2.01(1.41 \\
2.88)\end{array}$ & $1.40(1.03$ & 1.91) & 1.00 (referer & & $\begin{array}{l}2.56(1.49 \\
4.40)\end{array}$ & $0.92(0.53$ & 1.62) & 1.00 (refere & ce) \\
\hline $\begin{array}{l}\text { Excluding glucose-lowering } \\
\text { drugs }\end{array}$ & $\begin{array}{l}2.02(1.48 \\
2.76)\end{array}$ & $1.45(1.12$ & 1.88) & 1.00 (referer & ce) & $\begin{array}{l}2.70(1.68, \\
4.33)\end{array}$ & $1.08(0.69$ & 1.71) & 1.00 (refere & cce) \\
\hline Quartiles of LDL-C & Q1 & Q2 & Q3 & Q4 & $P_{\text {trend }} \mathrm{b}$ & Q1 & Q2 & Q3 & Q4 & $P_{\text {trend }}$ \\
\hline Number & 2343 & 2333 & 2327 & 2324 & & 2343 & 2333 & 2327 & 2324 & \\
\hline Case/person-years & $\begin{array}{l}153 / 20 \\
356\end{array}$ & $\begin{array}{l}108 / 21 \\
562\end{array}$ & $72 / 21,893$ & $55 / 22,040$ & & $60 / 20,800$ & $40 / 21,824$ & $23 / 22,088$ & $22 / 22,199$ & \\
\hline Mean $L D L-C \pm S D, m g / d L$ & $\begin{array}{l}38.1 \pm \\
12.0\end{array}$ & $\begin{array}{l}55.3 \pm \\
2.43\end{array}$ & $\begin{array}{l}62.1 \pm \\
1.59\end{array}$ & $67.2 \pm 1.38$ & & $\begin{array}{l}38.1 \pm \\
12.0\end{array}$ & $\begin{array}{l}55.3 \pm \\
2.43\end{array}$ & $\begin{array}{l}62.1 \pm \\
1.59\end{array}$ & $67.2 \pm 1.38$ & \\
\hline Multivariate model $^{a}$ & $\begin{array}{l}2.39(1.69 \\
3.39)\end{array}$ & $\begin{array}{l}2.40(1.69 \\
3.41)\end{array}$ & $\begin{array}{l}1.48(1.02 \\
2.16)\end{array}$ & $\begin{array}{l}1.00 \\
\text { (reference) }\end{array}$ & $\begin{array}{l}< \\
0.001\end{array}$ & $\begin{array}{l}2.14(1.24 \\
3.69)\end{array}$ & $\begin{array}{l}1.89(1.08 \\
3.31)\end{array}$ & $\begin{array}{l}1.13(0.61 \\
2.11)\end{array}$ & $\begin{array}{l}1.00 \\
\text { (reference) }\end{array}$ & 0.002 \\
\hline $\begin{array}{l}\text { Excluding eGFR }<60 \mathrm{ml} / \mathrm{min} / \\
1.73 \mathrm{~m}^{2}\end{array}$ & $\begin{array}{l}2.76(1.89 \\
4.03)\end{array}$ & $\begin{array}{l}2.68(1.84 \\
3.92)\end{array}$ & $\begin{array}{l}1.61(1.07 \\
2.42)\end{array}$ & $\begin{array}{l}1.00 \\
\text { (reference) }\end{array}$ & $\begin{array}{l}< \\
0.001\end{array}$ & $\begin{array}{l}2.11(1.20 \\
3.72)\end{array}$ & $\begin{array}{l}1.87(1.05 \\
3.32)\end{array}$ & $\begin{array}{l}1.20(0.64 \\
2.25)\end{array}$ & $\begin{array}{l}1.00 \\
\text { (reference) }\end{array}$ & 0.004 \\
\hline $\begin{array}{l}\text { Excluding Framingham risk } \\
\text { score }>30 \%\end{array}$ & $\begin{array}{l}2.67(1.63 \\
4.40)\end{array}$ & $\begin{array}{l}2.62(1.59 \\
4.30)\end{array}$ & $\begin{array}{l}1.58(0.93 \\
2.69)\end{array}$ & $\begin{array}{l}1.00 \\
\text { (reference) }\end{array}$ & $\begin{array}{l}< \\
0.001\end{array}$ & $\begin{array}{l}2.34(1.07 \\
5.13)\end{array}$ & $\begin{array}{l}1.99(0.89, \\
4.46)\end{array}$ & $\begin{array}{l}1.53(0.66, \\
3.55)\end{array}$ & $\begin{array}{l}1.00 \\
\text { (reference) }\end{array}$ & 0.032 \\
\hline Excluding $\mathrm{BMI}<18.5 \mathrm{~kg} / \mathrm{m}^{2}$ & $\begin{array}{l}2.40 \text { (1.70, } \\
3.41)\end{array}$ & $\begin{array}{l}2.41 \text { (1.70, } \\
3.42)\end{array}$ & $\begin{array}{l}1.47(1.01 \\
2.15)\end{array}$ & $\begin{array}{l}1.00 \\
\text { (reference) }\end{array}$ & $\begin{array}{l}< \\
0.001\end{array}$ & $\begin{array}{l}2.13(1.23 \\
3.68)\end{array}$ & $\begin{array}{l}1.92(1.10 \\
3.37)\end{array}$ & $\begin{array}{l}1.09(0.58 \\
2.05)\end{array}$ & $\begin{array}{l}1.00 \\
\text { (reference) }\end{array}$ & 0.002 \\
\hline $\begin{array}{l}\text { Excluding blood pressure- } \\
\text { lowering drugs }\end{array}$ & $\begin{array}{l}2.38(1.56 \\
3.63)\end{array}$ & $\begin{array}{l}2.32(1.51 \\
3.55)\end{array}$ & $\begin{array}{l}1.53(0.97 \\
2.41)\end{array}$ & $\begin{array}{l}1.00 \\
\text { (reference) }\end{array}$ & $\begin{array}{l}< \\
0.001\end{array}$ & $\begin{array}{l}2.01(1.04 \\
3.87)\end{array}$ & $\begin{array}{l}1.68(0.85 \\
3.33)\end{array}$ & $\begin{array}{l}1.05(0.49 \\
2.23)\end{array}$ & $\begin{array}{l}1.00 \\
\text { (reference) }\end{array}$ & 0.013 \\
\hline $\begin{array}{l}\text { Excluding glucose-lowering } \\
\text { drugs }\end{array}$ & $\begin{array}{l}2.37(1.65 \\
3.39)\end{array}$ & $\begin{array}{l}2.36(1.64 \\
3.38)\end{array}$ & $\begin{array}{l}1.39(0.94 \\
2.05)\end{array}$ & $\begin{array}{l}1.00 \\
\text { (reference) }\end{array}$ & $\begin{array}{l}< \\
0.001\end{array}$ & $\begin{array}{l}2.15(1.23 \\
3.75)\end{array}$ & $\begin{array}{l}1.79(1.00 \\
3.19)\end{array}$ & $\begin{array}{l}1.18(0.63 \\
2.21)\end{array}$ & $\begin{array}{l}1.00 \\
\text { (reference) }\end{array}$ & 0.002 \\
\hline
\end{tabular}

Abbreviations: $H R$, hazard ratio; $C l$, confidence interval; $L D L-C$, low-density lipoprotein cholesterol; $S D$, standard deviation; eGFR, estimated glomerular filtration rate; $B M I$, body mass index

${ }^{a}$ All models were adjusted for sex (men or women), age (year), physical activity (inactive, moderately active, or vigorously active), smoking and drinking status (never, former, occasional or daily), blood pressure status during follow-up (well-controlled or poorly controlled), blood glucose status during follow-up (wellcontrolled or poorly controlled), body mass index $\left(\mathrm{kg} / \mathrm{m}^{2}\right)$, urine protein (negative, trace,,+++ , or +++$)$, heart rate $(\mathrm{bpm})$, triglyceride $(\mathrm{mg} / \mathrm{dL})$, high-density lipoprotein cholesterol (mg/dL), low-density lipoprotein cholesterol $(\mathrm{mg} / \mathrm{dL})$, estimated glomerular filtration rate $\left(\mathrm{ml} / \mathrm{min} / 1.73 \mathrm{~m}{ }^{2}\right)$, and high-sensitivity C-reactive protein $(\mathrm{mg} / \mathrm{L})$

${ }^{\mathrm{b}}$ Test for trend according to the variable containing the median value of each quartile

implied that a smaller proportion of high-risk participants was included in the validation analysis. The sample size of our study $(\mathrm{n}=9327)$ was relatively small because of our strict inclusion criteria, and we thus identified a small number of incident ischemic stroke events $(\mathrm{n}=$ $388)$ and hemorrhagic stroke events $(n=145)$ during follow-up, which limited the detection of some potential weak-to-moderate predictors because of inadequate statistical power in each terminal node, the stopping rules or the competitive importance of the variables/pruning procedure. The small number of incident ischemic stroke events $(n=20)$ and hemorrhagic stroke events (n $=8$ ) limited the detection of significant predictive combinations in the validation set, and we could not swap 
the train and validation set to confirm the results. However, similar associations were observed in both cohorts. We did not measure hemoglobin A1c because of its high cost as a screening test in the general population, and some individuals with poorly controlled blood glucose could be misclassified. The proportion of hemorrhagic stroke in our cohort with LDL-C concentrations $<70$ $\mathrm{mg} / \mathrm{dL}$ was higher than that in the general population [18] because the ischemic stroke events attributed to high LDL-C concentrations were excluded. Further study or publicly datasets with repeated LDL-C concentrations may help to validate our results.

\section{Conclusions}

In a Chinese population with LDL-C concentrations < $70 \mathrm{mg} / \mathrm{dL}$, very low concentrations of LDL-C, incorporating poorly controlled blood pressure, and older age significantly predicted the occurrence of ischemic stroke and hemorrhagic stroke. Additional data are required to confirm our findings in a population with different ethnic and social-economic backgrounds.

\section{Abbreviations}

Cl: Confidence interval; CVD: Cardiovascular diseases; HR: Hazard ratio; ICD: International Classification of Diseases; LDL-C: Low-density lipoprotein cholesterol; SCTREE: Survival conditional inference tree

\section{Supplementary Information}

The online version contains supplementary material available at https://doi. org/10.1186/s12916-021-02014-4.

\begin{abstract}
Additional file 1. Table S1. Explanatory notes for all clinical characteristics included in the survival conditional inference tree model. Table S2. The risk of ischemic stroke and hemorrhagic stroke, according to the status of top three predictors, identified by the survival conditional inference tree model, in the Kailuan I study participants with low density lipoprotein cholesterol concentrations $<70 \mathrm{mg} / \mathrm{dL}$. Table S3. Area under receiver operating characteristic curves and brier score for ischemic stroke and hemorrhagic stroke in Kailuan I study participants with low density lipoprotein cholesterol concentrations $<70 \mathrm{mg} / \mathrm{dL}$. Fig. S1. Flow charts showing the selection strategy of individuals with low density lipoprotein cholesterol concentrations $<70 \mathrm{mg} / \mathrm{dL}$ in the Kailuan I study and Kailuan II study. Fig. S2. The variable importance of all predictors from the random survival forest analysis for ischemic stroke and hemorrhagic stroke. Fig. S3. Conditional inference tree for ischemic stroke vs non-ischemic stroke in individuals with baseline and cumulative average low density lipoprotein cholesterol concentrations $<70 \mathrm{mg} / \mathrm{dL}$. Fig S4. Conditional inference tree for hemorrhagic stroke vs non-hemorrhagic stroke in individuals with baseline and cumulative average low density lipoprotein cholesterol concentrations $<70 \mathrm{mg} / \mathrm{dL}$.
\end{abstract}

\section{Acknowledgements}

None.

\section{Authors' contributions}

$Z W, Z H$, and $X G$ contributed to the concept formation and design of the study protocol and interpretation of the data. ZW, AHL, SC, LB, and YJ managed the data, suggested the analytical strategy, and performed the data analysis. ZW, YL, MN, and XG drafted the article. ZW, SW, and XG designed the study, managed the data, and drafted the manuscript. All other authors contributed to the study design and data acquisition. All authors revised and approved the final article.

\section{Funding}

This work was supported by the start-up grant from the College of Health and Human Development and the Department of Nutritional Sciences, Penn State University (to Gao); the Shanghai Municipal Education CommissionGaofeng Clinical Medicine Grant Support (20172004; to Wu); and the National Institute of Allergy and Infectious Diseases of the National Institutes of Health (R01Al136664; to Bao). The funding sources had no role in the study design, data collection, analysis and interpretation of the data, writing of the report, and in the decision to submit the paper for publication.

\section{Availability of data and materials}

The dataset analyzed during the current study is not publicly available since the consent obtained from the participants did not include permission for their data to be shared publicly. However, the data are available from the principal investigator (Shouling $\mathrm{Wu}$ ) on reasonable request.

\section{Declarations}

\section{Ethics approval and consent to participate}

The study was approved by the Ethics Committee of the Kailuan General Hospital. The Kailuan Study was registered at the International Clinical Trials Registry Platform (http://apps.who.int/trialsearch/Trial2.aspx? TriallD=ChiCTRTNRC-11001489) with study ID number: ChiCTR-TNRC-11001489. All participants had provided written informed consent.

\section{Consent for publication}

Not applicable.

\section{Competing interests}

The authors declare that they have no competing interests.

\section{Author details}

${ }^{1}$ Department of Cardiology, Ruijin Hospital, Shanghai Jiaotong University School of Medicine, Shanghai, People's Republic of China. ${ }^{2}$ Department of Cardiology, Kailuan General Hospital, 57 Xinhua East Rd, Tangshan 063000, People's Republic of China. ${ }^{3}$ Cardiovascular Nutrition Laboratory, JM USDA Human Nutrition Research Center on Aging, Tufts University, Boston, MA, USA. ${ }^{4}$ Department of Neurology, Kailuan General Hospital, Tangshan, People's Republic of China. ${ }^{5}$ Health Care Center, Kailuan Medical Group, Tangshan, People's Republic of China. ${ }^{6}$ Department of Nutritional Sciences, The Pennsylvania State University, State College, PA, USA. ${ }^{7}$ Department of Statistics, The Pennsylvania State University, 109 Chandlee Lab, State College, University Park, PA 16802, USA.

Received: 12 February 2021 Accepted: 20 May 2021

Published online: 16 June 2021

References

1. Ference BA, Graham I, Tokgozoglu L, Catapano AL. Impact of lipids on cardiovascular health: JACC Health Promotion Series. J Am Coll Cardiol. 2018;72(10):1141-56. https://doi.org/10.1016/j.jacc.2018.06.046.

2. Stone NJ, Robinson JG, Lichtenstein AH, Bairey Merz CN, Blum CB, Eckel RH, et al. 2013 ACC/AHA Guideline on the treatment of blood cholesterol to reduce atherosclerotic cardiovascular risk in adults: a report of the American College of Cardiology/American Heart Association Task Force on Practice Guidelines. J Am Coll Cardiol. 2014;63(25 Pt B):2889-934.

3. European Association for Cardiovascular P, Rehabilitation, Reiner Z, Catapano AL, De Backer G, Graham I, Taskinen MR, et al. ESC/EAS Guidelines for the management of dyslipidaemias: the Task Force for the management of dyslipidaemias of the European Society of Cardiology (ESC) and the European Atherosclerosis Society (EAS). Eur Heart J. 2011;32(14):1769-818.

4. Laufs U, Karmann B, Pittrow D. Atorvastatin treatment and LDL cholesterol target attainment in patients at very high cardiovascular risk. Clin Res Cardiol. 2016;105(9):783-90.

5. Nayor M, Vasan RS. Recent update to the US Cholesterol Treatment Guidelines: a comparison with international guidelines. Circulation. 2016; 133(18):1795-806. https://doi.org/10.1161/CIRCULATIONAHA.116.021407.

6. Cheng KH, Lin JR, Anderson CS, Lai WT, Lee TH, Group S. Lipid paradox in statin-naive acute ischemic stroke but not hemorrhagic stroke. Front Neurol. 2018;9:541. https://doi.org/10.3389/fneur.2018.00541. 
7. Ma C, Na M, Neumann S, Gao X. Low-density lipoprotein cholesterol and risk of hemorrhagic stroke: a systematic review and dose-response metaanalysis of prospective studies. Curr Atheroscler Rep. 2019;21(12):52. https:// doi.org/10.1007/s11883-019-0815-5.

8. Rist PM, Buring JE, Ridker PM, Kase CS, Kurth T, Rexrode KM. Lipid levels and the risk of hemorrhagic stroke among women. Neurology. 2019.

9. Ma C, Gurol ME, Huang Z, Lichtenstein AH, Wang X, Wang Y, et al. Lowdensity lipoprotein cholesterol and risk of intracerebral hemorrhage: a prospective study. Neurology. 2019;93(5):e445-57. https://doi.org/10.1212/ WNL.0000000000007853.

10. Inza I, Calvo B, Armananzas R, Bengoetxea E, Larranaga P, Lozano JA. Machine learning: an indispensable tool in bioinformatics. Methods Mol Biol. 2010;593:25-48. https://doi.org/10.1007/978-1-60327-194-3_2.

11. Salis KL, Kliem S, O'Leary KD. Conditional inference trees: a method for predicting intimate partner violence. J Marital Fam Ther. 2014;40(4):430-41. https://doi.org/10.1111/jmft.12089.

12. Wu Z, Su X, Sheng H, Chen Y, Gao X, Bao L, et al. Conditional inference tree for multiple gene-environment interactions on myocardial infarction. Arch Med Res. 2017:48(6):546-52. https://doi.org/10.1016/j.arcmed.2017.12.001.

13. Li S, Cheng J, Cui L, Gurol ME, Bhatt DL, Fonarow GC, et al. Cohort study of repeated measurements of serum urate and risk of incident atrial fibrillation. J Am Heart Assoc. 2019;8(13):e012020. https://doi.org/10.1161/JAHA.119.012 020.

14. Wu S, Jin C, Li S, Zheng X, Zhang X, Cui L, et al. Aging, arterial stiffness, and blood pressure association in Chinese adults. Hypertension. 2019;73(4):8939. https://doi.org/10.1161/HYPERTENSIONAHA.118.12396.

15. Gu X, Li Y, Chen S, Yang X, Liu F, Li Y, et al. Association of lipids with ischemic and hemorrhagic stroke: a prospective cohort study among 267 500 Chinese. Stroke. 2019;50(12):3376-84. https://doi.org/10.1161/STROKEA HA. 119.026402 .

16. Jin C, Li G, Rexrode KM, Gurol ME, Yuan X, Hui Y, et al. Prospective study of fasting blood glucose and intracerebral hemorrhagic risk. Stroke. 2018;49(1): 27-33. https://doi.org/10.1161/STROKEAHA.117.019189.

17. Barta A. ICD-10-CM official coding guidelines. J AHIMA. 2009;80(6):70-1.

18. Li W, Jin C, Vaidya A, Wu Y, Rexrode K, Zheng $X$, et al. Blood pressure trajectories and the risk of intracerebral hemorrhage and cerebral infarction: a prospective study. Hypertension. 2017;70(3):508-14. https://doi.org/10.11 61/HYPERTENSIONAHA.117.09479.

19. Stroke--1989. Recommendations on stroke prevention, diagnosis, and therapy. Report of the WHO Task Force on Stroke and other Cerebrovascular Disorders. Stroke. 1989;20(10):1407-31.

20. Wu Z, Huang Z, Jin W, Rimm EB, Lichtenstein AH, Kris-Etherton PM, et al. Peripheral inflammatory biomarkers for myocardial infarction risk: a prospective community-based study. Clin Chem. 2017;63(3):663-72. https:// doi.org/10.1373/clinchem.2016.260828.

21. Wu S, An S, Li W, Lichtenstein AH, Gao J, Kris-Etherton PM, et al. Association of trajectory of cardiovascular health score and incident cardiovascular disease. JAMA Netw Open. 2019;2(5):e194758. https://doi.org/10.1001/jama networkopen.2019.4758

22. Li J, Huang Z, Hou J, Sawyer AM, Wu Z, Cai J, et al. Sleep and CKD in Chinese adults: a cross-sectional study. Clin J Am Soc Nephrol. 2017;12(6): 885-92.

23. Levey AS, Stevens LA, Schmid $\mathrm{CH}$, Zhang YL, Castro AF 3rd, Feldman HI, et al. A new equation to estimate glomerular filtration rate. Ann Intern Med. 2009:150(9):604-12. https://doi.org/10.7326/0003-4819-150-9-20090505000006.

24. Wang L, Cui L, Wang Y, Vaidya A, Chen S, Zhang C, et al. Resting heart rate and the risk of developing impaired fasting glucose and diabetes: the Kailuan prospective study. Int J Epidemiol. 2015;44(2):689-99. https://doi. org/10.1093/ije/dyv079.

25. Harrell FE Jr, Califf RM, Pryor DB, Lee KL, Rosati RA. Evaluating the yield of medical tests. JAMA. 1982;247(18):2543-6. https://doi.org/10.1001/jama.1982. 03320430047030.

26. Ambale-Venkatesh B, Yang X, Wu CO, Liu K, Hundley WG, McClelland R, et al. Cardiovascular event prediction by machine learning: the multi-ethnic study of atherosclerosis. Circ Res. 2017;121(9):1092-101. https://doi.org/10.11 61/CIRCRESAHA.117.311312.

27. Mach F, Baigent C, Catapano AL, Koskinas KC, Casula M, Badimon L, et al. ESC/EAS Guidelines for the management of dyslipidaemias: lipid modification to reduce cardiovascular risk. Eur Heart J. 2019:2019.
28. D'Agostino RB Sr, Vasan RS, Pencina MJ, Wolf PA, Cobain M, Massaro JM, et al. General cardiovascular risk profile for use in primary care: the Framingham Heart Study. Circulation. 2008;117(6):743-53. https://doi.org/1 0.1161/CIRCULATIONAHA.107.699579.

29. Kawate N, Kayaba K, Hara M, Kotani K, Ishikawa S, Jichi Medical School Cohort Study G. Body mass index and stroke incidence in Japanese community residents: the Jichi Medical School (JMS) Cohort Study. J Epidemiol. 2017;27(7):325-30. https://doi.org/10.1016/j.je.2016.08.007.

30. Breiman L. Random forests. Mach Learn. 2001;45(1):5-32. https://doi.org/10.1 023/A:1010933404324.

31. Ishwaran $\mathrm{H}$. Variable importance in binary regression trees and forests. Electron J Statist. 2007;1:519-37.

32. Perez-Baos S, Barrasa JI, Gratal P, Larranaga-Vera A, Prieto-Potin I, HerreroBeaumont $G$, et al. Tofacitinib restores the inhibition of reverse cholesterol transport induced by inflammation: understanding the lipid paradox associated with rheumatoid arthritis. Br J Pharmacol. 2017;174(18):3018-31. https://doi.org/10.1111/bph.13932.

33. Parker CR Jr, Carr BR, Simpson ER, MacDonald PC. Decline in the concentration of low-density lipoprotein-cholesterol in human fetal plasma near term. Metabolism. 1983;32(9):919-23. https://doi.org/10.1016/0026-04 95(83)90207-X.

34. Fujita H, Okada T, Inami I, Makimoto M, Hosono S, Minato M, et al. Lowdensity lipoprotein profile changes during the neonatal period. J Perinatol. 2008;28(5):335-40

35. Pac-Kozuchowska E. Evaluation of lipids, lipoproteins and apolipoproteins concentrations in cord blood serum of newborns from rural and urban environments. Ann Agric Environ Med. 2007;14(1):25-9.

36. Brown MS, Goldstein JL. A receptor-mediated pathway for cholesterol homeostasis. Science. 1986;232(4746):34-47. https://doi.org/10.1126/ science. 3513311.

37. Penson PE, Long DL, Howard G, Toth PP, Muntner P, Howard VJ, et al. Associations between very low concentrations of low density lipoprotein cholesterol, high sensitivity C-reactive protein, and health outcomes in the Reasons for Geographical and Racial Differences in Stroke (REGARDS) study. Eur Heart J. 2018;39(40):3641-53. https://doi.org/10.1093/eurheartj/ehy533.

38. High-dose atorvastatin after stroke or transient ischemic attack. N Engl J Med. 2018;378(25):2450.

39. Sun L, Clarke R, Bennett D, Guo Y, Walters RG, Hill M, et al. Causal associations of blood lipids with risk of ischemic stroke and intracerebral hemorrhage in Chinese adults. Nat Med. 2019;25(4):569-74. https://doi.org/1 0.1038/s41591-019-0366-x

40. Ference BA, Robinson JG, Brook RD, Catapano AL, Chapman MJ, Neff DR, et al. Variation in PCSK9 and HMGCR and risk of cardiovascular disease and diabetes. N Engl J Med. 2016;375(22):2144-53. https://doi.org/10.1056/ NEJMoa1604304.

41. Grundy SM, Stone NJ, Bailey AL, Beam C, Birtcher KK, Blumenthal RS, et al. AHA/ACC/AACVPR/AAPA/ABC/ACPM/ADA/AGS/APhA/ASPC/NLA/PCNA Guideline on the management of blood cholesterol. Circulation. 2018;2018: CIR0000000000000625.

42. Alloubani A, Saleh A, Abdelhafiz I. Hypertension and diabetes mellitus as a predictive risk factors for stroke. Diabet Metab Synd. 2018;12(4):577-84. https://doi.org/10.1016/j.dsx.2018.03.009.

43. Schwartz GG, Steg PG, Szarek M, Bhatt DL, Bittner VA, Diaz R, et al. Alirocumab and cardiovascular outcomes after acute coronary syndrome. N Engl J Med. 2018;379(22):2097-107. https://doi.org/10.1056/NEJMoa1801174.

\section{Publisher's Note}

Springer Nature remains neutral with regard to jurisdictional claims in published maps and institutional affiliations. 